\title{
The distribution of homologues of the Escherichia coli KefC K+-efflux system in other bactèrial species
}

\author{
Roseileen M. Douglas, Jennifer A. Roberts, $\dagger$ Andrew W. Munro, $\ddagger$ Graeme Y. Ritchie, \\ ANDREW J. LAMB and IAN R. BOOTH*
}

Department of Molecular and Cell Biology, University of Aberdeen, Marischal College, Aberdeen AB9 1AS, UK

(Received 12 March 1991; revised 29 April 1991; accepted 13 May 1991)

\begin{abstract}
Using a variety of techniques the distribution of the glutathione-regulated $\mathrm{KefC} \mathrm{K}^{+}$-transport system among bacterial species was investigated. The presence of similar systems in a number of Gram-negative bacteria was demonstrated. In contrast, the system appeared to be absent from most Gram-positive bacteria tested with the exception of Staphylococcus aureus. Using the cloned Escherichia coli kefC gene as a probe for Southern hybridization it was shown that only limited DNA sequence homology exists with other bacteria, even when closely related members of the enteric group were examined.
\end{abstract}

\section{Introduction}

$\mathrm{K}^{+}$is accumulated to high concentrations in the bacterial cytoplasm and has been recognized to serve important roles in bacterial cells (Epstein, 1986). Although not proven for all bacteria, the role of $\mathrm{K}^{+}$in turgor regulation is considered to be of central importance. In Escherichia coli control over $\mathrm{K}^{+}$accumulation is the major mechanism of turgor regulation (Epstein, 1986) and the size of the cytoplasmic $\mathrm{K}^{+}$pool is determined primarily by the osmotic pressure of the environment (Epstein \& Schultz, 1965). Regulation of both influx and efflux processes for $\mathrm{K}^{+}$has been demonstrated (Rhoads \& Epstein, 1978; Meury et al., 1985; Bakker et al., 1987), which allows the cell to adapt to both low and high turgor. $\mathrm{K}^{+}$uptake is accomplished by at least three systems, Kdp, Kup and Trk (Bossemeyer et al., 1989a; Epstein, 1986). It has recently been suggested that the Trk system is the sum of two activities TrkG and TrkH (Dosch et al., 1991). The Kup and Trk systems are constitutive while the Kdp system is induced by conditions that affect the ability of the cell to maintain turgor (Laimins et al., 1981; Bossemeyer et al., 1989b); the transport activity of each of the three systems is regulated by turgor pressure.

† Present address: Institute of Genetics, University of Glasgow, Glasgow, UK.

$\ddagger$ Present address: Department of Biochemistry, University of Glasgow, Glasgow, UK.

\footnotetext{
Abbreviations: ESG, $N$-ethylsuccinimido- $S$-glutathione; GST, glutathione $S$-transferase; NEM, $N$-ethylmaleimide.
}

There are at least three $\mathrm{K}^{+}$-efflux systems in E. coliKef B, KefC and a third system (now called KefA; W. Epstein, personal communication) that is evident in strains that lack Kef B and KefC activity (Bakker et al., 1987). The kefB and kefC (formerly trkB and trkC; Epstein \& Kim, 1971; Booth et al., 1985) loci encode two separate $\mathrm{K}^{+}$-efflux systems that are inhibited by glutathione and are activated by specific glutathione metabolites (Meury et al., 1980; Booth et al., 1985; Bakker et al., 1987; Elmore et al., 1990). The KefC system has been characterized in most detail at both the physiological and the molecular level (Elmore et al., 1990; Munro et al., 1991). The KefC system is activated by glutathione metabolites that possess hydrophobic additions to the sulphydryl group of the cysteine of the peptide (Elmore et al., 1990). Thus, $N$-ethylsuccinimido- $S$-glutathione (ESG), $N$-phenylsuccinimido- $S$-glutathione and 2,4-dinitrophenyl-S-glutathione activate the $\mathrm{KefC}$ system, but glutathione itself and $S$-carboxymethylglutathione do not produce significant activation and, indeed, reduce the activity of the KefC system (Elmore et al., 1990; A. J. Lamb \& I. R. Booth, unpublished data). The kefC gene from $E$. coli has recently been cloned and the DNA sequence determined (Munro et al., 1991). The DNA sequence encodes a polypeptide of 620 amino acids, the sequence of which bears some similarity to bacterial enzymes that utilize glutathione (Munro et al., 1991; K. T. Douglas, personal communication).

The present study was undertaken to determine the distribution of the $\mathrm{KefC}$ class of transport system among bacteria other than $E$. coli. We report that the transport 
system appears to be widely distributed among Gramnegative bacterial species but is absent from all the Gram-positive bacteria tested with the exception of Staphylococcus aureus.

\section{Methods}

Bacterial strains. Escherichia coli 3000, Salmonella typhimurium LT2, Pseudomonas aeruginosa, Staphylococcus caseolyticus NCIMB 11374, Streptococcus faecalis NCIMB 775, Streptococcus lactis NCIMB 6681, Erwinia carotovora, Lactobacillus casei ATCC 335, Staphylococcus aureus, Bacillus cereus and Enterobacter aerogenes were from the Departmental culture collection; Azospirillum brasilense NCIMB 11860 was obtained from the NCIMB, University of Aberdeen, UK. Rhodobacter sphaeroides NCIMB 8253 was obtained from Dr N. Hunter (University of Sheffield, UK).

Media for growth and transport assays. The minimal media $\mathbf{K}_{x}$ [where $x$ indicates the $\mathrm{K}^{+}$concentration (mM)] was used for the culture of cells and for transport experiments (Epstein \& Kim, 1971). Complex medium LK (Rowland et al., 1984) was used for cell growth for DNA manipulations.

Growth conditions. Cells were grown either in $\mathrm{K}_{120}$ minimal medium (Epstein \& $\mathrm{Kim}, 1971)$ at $37^{\circ} \mathrm{C}$ containing glucose $(0.2 \%)$ as sole carbon source or in LK medium (Rowland et al., 1984). Some strains ( $R$. sphaeroides, Az. brasilense, Staph. caseolyticus, Strep. faecalis, Strep. lactis, Er. carotovora, L. casei) were grown at $28^{\circ} \mathrm{C}$. $R$. sphaeroides was grown aerobically in the dark.

Measurement of $\mathrm{K}^{+}$efflux. Overnight cultures of the appropriate strain were diluted into fresh growth medium and grown to an $\mathrm{OD}_{650}$ of approximately $1 \cdot 0$. An aliquot of cells $(25 \mathrm{ml})$ was then harvested by filtration (Millipore; $0.45 \mu \mathrm{m}, 4.5 \mathrm{~cm}$ ) and washed with $5 \mathrm{ml} \mathrm{K} \mathrm{K}_{10}$ medium. The cells were then suspended by vortexing in a boiling-tube containing $25 \mathrm{ml} \mathrm{K}$ medium and the cell suspension was divided equally between two thermally insulated glass vessels maintained at $37^{\circ} \mathrm{C}$. Zero time for experiments was taken from the time of suspension. Additions were made as required from 100-fold concentrated stock solutions. At intervals $1 \mathrm{ml}$ samples were removed by Gilson pipette and transferred to Eppendorf tubes, and the cells collected by centrifugation at full speed for $30 \mathrm{~s}$. The supernatant was then removed by aspiration, the pellet suspended in $1 \mathrm{ml}$ of distilled water and $\mathrm{K}^{+}$liberated from the cells by boiling for $5 \mathrm{~min}$ in a rack designed to keep the Eppendorf tubes closed. Cell debris was then removed by centrifugation and the potassium content of the supernatant measured by flame photometry (Corning $\mathbf{4 0 0}$ flame photometer).

Assay of glutathione. This was done as described previously (Elmore et al. 1990).

DNA manipulations. Chromosomal DNA was prepared by the method modified from Davis et al. (1980). Cells $(400 \mathrm{ml})$ in early exponential phase $\left(\mathrm{OD}_{650} 0 \cdot 3\right)$ were harvested by centrifugation and suspended in $5 \mathrm{ml} 25 \%(\mathrm{w} / \mathrm{v})$ sucrose in $50 \mathrm{~mm}-\mathrm{Tris} / \mathrm{HCl}, \mathrm{pH} 8$, and $10 \mathrm{mg}$ lysozyme was added. The cells were mixed and incubated at $30^{\circ} \mathrm{C}$ for $10 \mathrm{~min}$. [This procedure was modified for Staph. aureus by the addition of $1 \mathrm{mg}$ lysostaphin (Sigma) in place of lysozyme and the incubation temperature was raised to $37^{\circ} \mathrm{C}$.] After a further $10 \mathrm{~min}$ incubation on ice $5 \mathrm{ml} 0.2 \mathrm{M}-\mathrm{Na}_{2} \mathrm{EDTA}, \mathrm{pH} 8$, was added and the tubes were shaken gently and placed on ice for $10 \mathrm{~min}$. This incubation was followed by the addition of $1 \mathrm{ml}$ SDS $(10 \%, \mathrm{w} / \mathrm{v})$ and the tubes were shaken until the cell suspension cleared. If the suspension remained viscous, $10 \mathrm{ml} 50 \mathrm{mM}$-EDTA, pH $8 \cdot 5$, containing $0 \cdot 2 \%$ (w/v) SDS was added and the suspension was heated to $65^{\circ} \mathrm{C}$ for $10 \mathrm{~min}$. Streptococcal

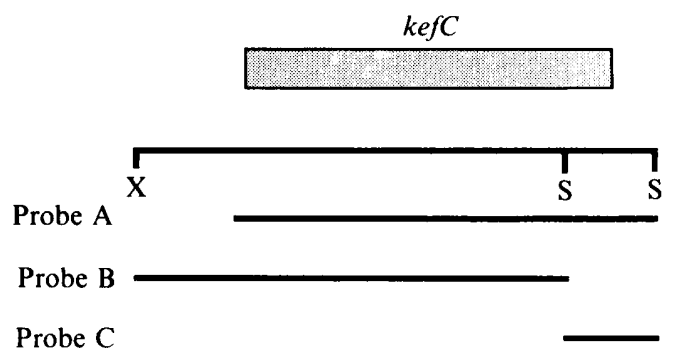

Fig. 1. Regions of the $k e f C$ gene used as probes in Southern hybridization. DNA probes were produced by restriction digestion of plasmids pkC8 and pkC6-16 (Munro et al., 1991). The hatched area represents the limits of the kefC gene; $\mathrm{X}, \mathrm{XhoI}$ site; $\mathrm{S}$, SalI site.

cells were difficult to lyse and cell disruption was found to be assisted by raising the temperature to $70-75^{\circ} \mathrm{C}$ (Marmur, 1961). A 1/5th vol. of $5 \mathrm{M}$-potassium acetate (Maniatis et al. 1982) was added to the lysed cells and the solutions mixed by gentle inversion of the tubes. After incubating the mixture on ice for at least $30 \mathrm{~min}$ the protein precipitate was removed by centrifugation at $20000 \mathrm{~g}$ for $20 \mathrm{~min}$ at $4{ }^{\circ} \mathrm{C}$. The supernatant was decanted into a fresh sterile tube and ethanol added, and precipitation of the DNA aided by incubation at $-20^{\circ} \mathrm{C}$ for $30 \mathrm{~min}$. The DNA was spooled onto a fine glass-rod, dried and dissolved in 1-2 ml Tris/EDTA (TE) buffer, pH 7.5 (Maniatis et al., 1982). RNA and residual protein were removed by treatment with RNAase $A$ and proteinase $K$, respectively, followed by phenol extraction and ethanol precipitation as described by Maniatis $e t$ al. (1982); the purified DNA was dissolved in a small volume of TE buffer, $\mathrm{pH} 7 \cdot 5$.

Additional DNA from $R$. sphaeroides and Anacystis nidulans was supplied by N. Hunter (University of Sheffield, UK) and E. Padan (University of Jerusalem, Israel), respectively.

DNA fragments for use as probes were derived from plasmids pkC8 and pkC6-16 (Munro et al., 1991) (Fig. 1). The fragments were labelled with $\left[\alpha^{-32} \mathrm{P}\right] \mathrm{dCTP}$ [specific activity $\left.3000 \mathrm{Ci} \mathrm{mol}^{-1}\left(111 \mathrm{TBq} \mathrm{mol}^{-1}\right)\right]$ using the random oligonucleotide primer method (Feinberg \& Vogelstein, 1983). The labelled DNA was purified by column chromatography (Stratagene Push column) to give probes with specific activities of $10^{8}-10^{9}$ c.p.m. $(\mu \mathrm{g} \text { DNA })^{-1}$.

Restriction enzyme digestion, gel electrophoresis and Southern hybridization were performed according to Maniatis et al. (1982). DNA was transferred to GeneScreen Plus nylon membranes (Dupont). The blotted and hybridized membranes were given two final washes in $0.2 \times$ SSC, $0.1 \%$ SDS at $50{ }^{\circ} \mathrm{C}$. Washed blots were exposed to Fuji NIF $\mathrm{RX} X$-ray film at $-70{ }^{\circ} \mathrm{C}$ for $48 \mathrm{~h}$ prior to development.

\section{Results}

\section{Activation of $\mathrm{K}^{+}$efflux by $\mathrm{N}$-ethylmaleimide}

The activation of the KefC system can be achieved by the reaction of $N$-ethylmaleimide (NEM) with cellular glutathione to form the activator $N$-ethylsuccinimido$S$-glutathione (ESG) (Elmore et al., 1990). We therefore sought to elicit $\mathrm{K}^{+}$efflux from a range of bacteria by the addition of NEM $(0.5 \mathrm{mM}$ final concentration) to cells washed and suspended in $\mathrm{K}^{+}$-free medium (Fig. $2 a, b$ ). A typical efflux curve is shown for $P$. aeruginosa (Fig. 2a) 
(a)

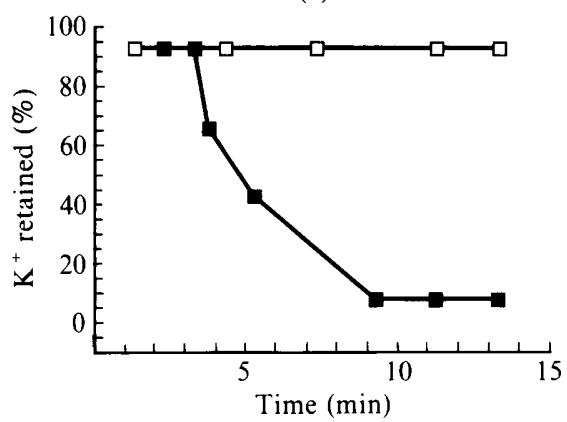

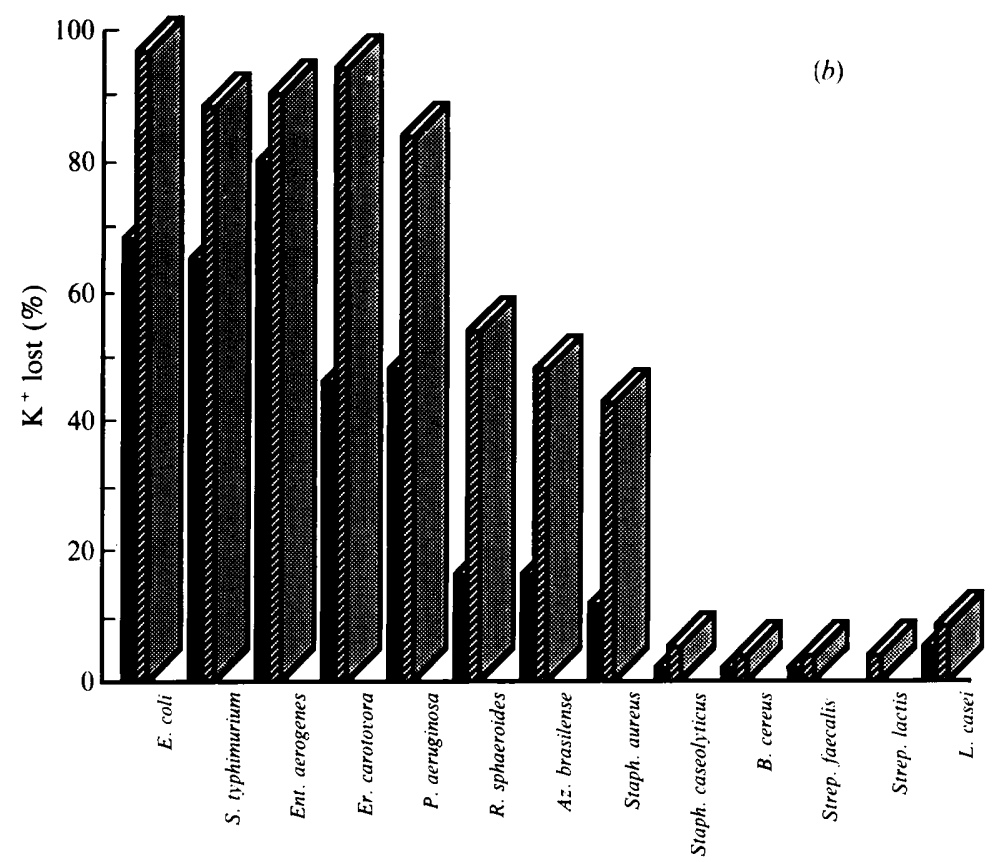

Fig. 2. NEM-elicited $\mathrm{K}^{+}$efflux from bacteria. (a) $\mathrm{K}^{+}$efflux from $P$. aeruginosa was elicited by addition of $0.5 \mathrm{mM}-\mathrm{NEM} 3 \mathrm{~min}$ after transfer of the cells to $K_{0}$ medium (zero time). The initial $\mathrm{K}^{+}$content of the cells was $350 \mathrm{ng}$-ion $\left(\mathrm{OD}_{650}\right.$ unit) ${ }^{-1}$. $\square$, No NEM; $\mathbf{\square}$, 0.5 mM-NEM. (b) NEM-elicited $\mathrm{K}^{+}$efflux was measured in experiments similar to that shown in $(a)$ and the $\mathrm{K}^{+}$lost by the cells 2 min (solid bars) and $18 \mathrm{~min}$ (stippled bars) after addition of $0.5 \mathrm{~mm}-\mathrm{NEM}$ is shown. The $\mathrm{K}^{+}$content of the cells in each case was approximately $350 \mathrm{ng}$-ion $\left(\mathrm{OD}_{650} \text { unit }\right)^{-1}$.

and the extent of $\mathrm{K}^{+}$efflux 2 min and 18 min after NEM addition is shown for the other species investigated (Fig. $2 b$ ). In control incubations, to which NEM was not added, $\mathrm{K}^{+}$efflux over the $18 \mathrm{~min}$ incubation was less than $4 \%$. Rapid $\mathrm{K}^{+}$efflux was observed in $S$. typhimurium, Ent aerogenes, Er. carotovora and $P$. aeruginosa, and the rate of $\mathrm{K}^{+}$efflux was similar to that observed in $E$. coli. However, the $\mathrm{K}^{+}$efflux systems of $R$. sphaeroides and $A z$. brasilense were much less active than for the above group of micro-organisms. NEM did not elicit $\mathrm{K}^{+}$ efflux from the Gram-positive organisms studied with the exception of Staph. aureus, which exhibited an activity that was similar to that observed in $R$. sphaeroides and $A z$. brasilense. The related species Staph. caseolyticus did not show the efflux of $\mathrm{K}^{+}$ exhibited by Staph. aureus (Fig. $2 b$ ).

\section{Involvement of glutathione in NEM-activated $\mathrm{K}^{+}$efflux}

SH reagents, such as NEM, could cause $\mathrm{K}^{+}$efflux either by their action on protein thiols or by their forming an activator of the KefC system. We have previously shown that the involvement of glutathione in the NEMactivation of $\mathrm{K}^{+}$efflux can be demonstrated by converting the glutathione pool to $S$-carboxymethyl- glutathione by treatment with iodoacetate. $S$-Carboxymethylglutathione is not a strong activator of the $E$. coli $\mathrm{KefC}$ system and subsequent incubation with NEM does not elicit $\mathrm{K}^{+}$efflux because there is no free glutathione to react with NEM and form ESG (Elmore et al., 1990). Re-incubation of iodoacetate-treated $E$. coli cells with glutathione leads to the re-establishment of the cytoplasmic glutathione pool and restoration of sensitivity of $\mathrm{K}^{+}$efflux to NEM (Elmore et al., 1990). We therefore sought to apply this protocol to the above group of organisms.

Iodoacetate treatment prevented the NEM-activation of $\mathrm{K}^{+}$efflux in each of the organisms that showed KefCtype activity. Incubation of cells with idoacetate $(1 \mathrm{mM}$ final concentration) for 10 min prevented significant $\mathrm{K}^{+}$ efflux upon addition of NEM. Incubation of iodoacetatetreated cells of Er. carotovora and Staph. aureus with $5 \mathrm{mM}$-glutathione for $20 \mathrm{~min}$ in the presence of chloramphenicol to inhibit protein synthesis restored $\mathrm{K}^{+}$efflux upon addition of NEM (Fig. $3 a, b$ ). The rate and extent of $\mathrm{K}^{+}$loss was similar to that observed in cell suspensions that had not been treated with iodoacetate (Fig. $2 b$ ). Similarly, in the other Gram-negative bacteria tested ( $R$. sphaeroides, Az. brasilense, $P$. aeruginosa, $S$. typhimurium and Ent. aerogenes), iodoacetate inhibited 

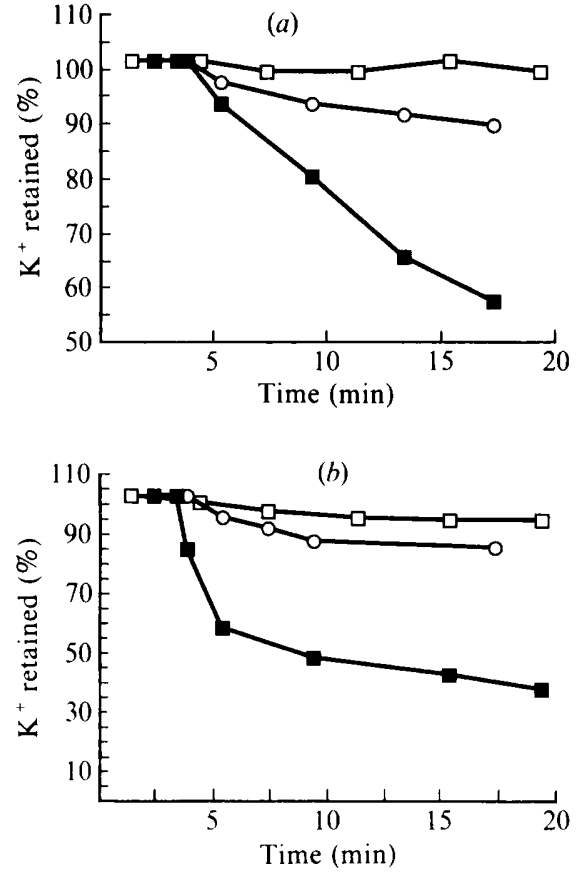

Fig. 3. Restoration of $\mathbf{K}^{+}$efflux in iodoacetate-treated cells by glutathione. Cells of Staph. aureus $(a)$ and Er. carotovora $(b)$ were treated with iodoacetate ( $1 \mathrm{mM}$ final concentration) and NEM (0.5 mM final concentration) added at $3 \mathrm{~min}(O)$. Alternatively, cells were treated as above with iodoacetate for $10 \mathrm{~min}$ and then washed and incubated for $20 \mathrm{~min}$ with $5 \mathrm{~mm}$-glutathione. The cells were then harvested by filtration and resuspended in $K_{0}$ medium. After incubation for $3 \mathrm{~min} 0.5 \mathrm{mM}-\mathrm{NEM}$ was added $(\boldsymbol{\nabla})$. The $\mathrm{K}^{+}$content of the cells at the time of NEM addition was approximately $350 \mathrm{ng}$-ion $\left(\mathrm{OD}_{650} \text { unit }\right)^{-1}$ in control cells $(\square)$ and was $15 \%$ and $30 \%$ lower in iodoacetate-treated cells of Staph. aureus and Er. carotovora, respectively.

NEM-elicited $\mathrm{K}^{+}$efflux by $73-84 \%$. Thus the behaviour of the cells is consistent with the presence of a transport system analogous to $\mathrm{KefC}$ in these organisms.

The NEM-activation of $\mathrm{K}^{+}$efflux in $E$. coli can be reversed, in the absence of protein synthesis, by treatment of the cells with a reducing agent such as dithiothreitol (DTT) (Meury et al., 1980; Bakker \& Mangerich, 1982). This reversal arises from the breakdown of ESG to release glutathione (Elmore et al., 1990) and from the release of glutathione from cellular dithiols (A. J. Lamb \& I. R. Booth, unpublished data). We have found that a similar reversal of the effects of iodoacetate can be effected by incubation with DTT. Thus iodoacetate-treated cells of Er. carotovora and Staph. aureus were incubated with $10 \mathrm{mM}$-DTT for $10 \mathrm{~min}$ in the presence of chloramphenicol to inhibit new protein synthesis; the cells were then filtered and suspended in fresh incubation medium. Addition of NEM ( $0.5 \mathrm{mM})$ provoked immediate loss of $\mathrm{K}^{+}$similar to that shown in
Table 1. Formation of $S$-carboxymethylglutathione and $N$ ethylsuccinimido-S-glutathione in bacteria

The formation of $N$-ethylsuccinimido- $S$-glutathione and $S$-carboxymethylglutathione was measured as described previously (Elmore et al., 1990); cells were labelled with $N$-ethyl[2,3-14 C]maleimide or iodo $\left[2-{ }^{14} \mathrm{C}\right]$ acetate and extracted with trichloroacetic acid. The acid-soluble pool was fractionated by thin-layer chromatography and the radioactive spots identified by autoradiography. Radioactive areas were removed from the plates and counted by liquid scintillation counting. All values are triplicate determinations and each experiment was repeated twice except those marked with an asterisk $\left(^{*}\right)$ which represent single determinations. ND, Not determined.

\begin{tabular}{lcc}
\hline \hline \multicolumn{1}{c}{ Organism } & $\begin{array}{c}S \text {-Carboxymethyl- } \\
\text { glutathione } \\
\text { [nmol (mg cells) }\end{array}$ & $\begin{array}{c}N \text {-Ethylsuccinimido- } \\
S \text {-glutathione } \\
\text { [nmol (mg cells) }\end{array}$ \\
\hline Escherichia coli & $12 \cdot 9 \pm 0 \cdot 1$ & $4 \cdot 8 \pm 0 \cdot 5$ \\
Salmonella typhimurium & $9 \cdot 7 \pm 0 \cdot 3$ & $8 \cdot 1 \pm 0 \cdot 6$ \\
Enterobacter aerogenes & $7 \cdot 4 \pm 0 \cdot 8$ & $10 \pm 0 \cdot 6$ \\
Erwinia carotovora & $8 \cdot 8 \pm 0 \cdot 1$ & $11 \pm 0 \cdot 7$ \\
Pseudomonas aeruginosa & $3 \cdot 7 \pm 0 \cdot 4$ & $6 \cdot 9 \pm 0 \cdot 6$ \\
Rhodobacter sphaeroides & $21 \pm 0 \cdot 2$ & $6 \cdot 7 \pm 0 \cdot 4$ \\
Azospirillum brasilense & $6 \cdot 8 \pm 0 \cdot 6$ & $3 \cdot 1 \pm 0 \cdot 1$ \\
Staphylococcus aureus & $3 \cdot 4 \pm 0 \cdot 1$ & $3 \cdot 1^{*}$ \\
Bacillus cereus & $7 \cdot 3 \pm 0 \cdot 2$ & $\mathrm{ND}$ \\
Streptococcus faecalis & $1 \cdot 3 \pm 0 \cdot 3$ & $5 \cdot 0^{*}$ \\
Streptococcus lactis & $0 \cdot 3 \pm 0 \cdot 1$ & $3 \cdot 9 \pm 0 \cdot 6$ \\
Lactobacillus casei & $1 \cdot 8 \pm 0 \cdot 1$ & $\mathrm{ND}$ \\
\hline \hline
\end{tabular}

Fig. 3 (data not shown). Similarly, in P. aeruginosa the prevention of NEM-activated $\mathrm{K}^{+}$efflux by iodoacetate could be overcome by treatment of the cells with DTT (data not shown).

Thus by these criteria the NEM-elicited $\mathrm{K}^{+}$efflux in these bacteria occurs via a KefC-type of transport system.

\section{Generation of glutathione adducts}

The activation of a $\mathrm{KefC}$ homologue requires the formation of the glutathione metabolites. The presence of glutathione in each of the species was investigated by assaying for the formation of $S$-carboxymethylglutathione when cells were incubated with iodoacetate. Metabolites were extracted from cells incubated with iodo $\left[2-{ }^{-14} \mathrm{C}\right]$ acetate $[1 \mathrm{mM}$ final concentration; $54 \mu \mathrm{Ci} \mu \mathrm{mol}^{-1}$ (2 $\left.\mathrm{MBq} \mu \mathrm{mol}^{-1}\right)$ specific activity] with trichloroacetic acid and subjected to chromatography on PEI-cellulose plates (Elmore et al., 1990). In each case a single major metabolite which had the same $R_{F}$ value as $S$-carboxymethylglutathione (Elmore et al., 1990) was detected by autoradiography and the amount of the metabolite was determined (Table 1). All of the Gramnegative species tested showed the formation of 
$S$-carboxymethylglutathione, but the levels of the metabolite were very low in the Gram-positive species with the exception of Staph. aureus and B. cereus (Table 1). Similarly, when cells were incubated with $N$-ethyl$\left[2,3^{-14} \mathrm{C}\right]$ maleimide all the organisms able to form $S$-carboxymethylglutathione with iodoacetate formed ESG (Table 1). Thus all species that showed NEMelicited $\mathrm{K}^{+}$efflux possessed significant glutathione pools. There was no correlation between the rate of $\mathrm{K}^{+}$ efflux and the size of the glutathione pool (compare Table 1 and Fig. 2). However, the two streptococci and $B$. cereus possess glutathione but did not show NEMelicited efflux, and thus must lack a KefC-type transport system.

\section{Distribution of genes homologous to kefC}

The presence of genes homologous to the $k e f C$ gene was investigated using Southern hybridization. Three probes were used to detect sequences homologous to kefC (Fig. 1). Probe $A$ is a full length probe (approximately $2 \cdot 1 \mathrm{~kb}$ ) that encodes all the information needed for KefC activity. The $5^{\prime}$-end of the probe lies just upstream of the $k e f C$ gene sequence and includes approximately $200 \mathrm{bp}$ of the downstream region (this extra sequence is noncoding DNA; Smith \& Calvo, 1980). Probe B extends from the $X h o I$ site $400 \mathrm{bp} 5^{\prime}$ to the start of the kefC gene and terminates at a SalI site within the $k$ efC gene and is thus lacking the coding region for the last 121 amino acids and the downstream region of probe A. Probe $\mathrm{C}$ carries the $0.5 \mathrm{~kb}$ Sal I-SalI region encoding the last 121 amino acids of the KefC protein and the downstream non-coding region (Munro et al., 1991). When DNA digested with PstI was probed with probe A strong hybridization was observed for E. coli, S. typhimurium and Ent. aerogenes; the hybridization to $P$. aeruginosa and Er. carotovora DNA was very weak (Fig. 4). The single band observed with $E$. coli DNA was $7 \mathrm{~kb}$ as predicted from the restriction map of this region (Smith \& Calvo, 1980). This suggests that the homology to the kef $B$ gene is too weak to be detected by Southern hybridization. With the $S$. typhimurium DNA two bands of approximately $1.4 \mathrm{~kb}$ and $2.8 \mathrm{~kb}$ were observed in the Pst I-digested DNA. To determine whether this represented two homologous sequences or a PstI site internal to the $k e f C$ gene, DNA digested with $E c o$ RI was investigated. A single band of approximately $8 \mathrm{~kb}$ was observed in EcoRI digests of $S$. typhimurium DNA indicating that the two bands observed in the Pst I digest arose from digestion at an internal PstI site. Two bands were also observed in the Pst I digest of Ent. aerogenes (approximately $1 \mathrm{~kb}$ and $2 \mathrm{~kb}$; Fig. 4). However, the origin of these two bands was not investigated further. No hybridization was observed to DNA from Gram- positive bacteria or from the other Gram-negative species.

Both S. typhimurium and Ent. aerogenes exhibited strong homology to $E$. coli kefC using probes A and B which cover the 5 -end of the gene, but only S. typhimurium exhibited strong hybridization to probe C (data not shown). This suggests that the $3^{\prime}$-end of the gene has diverged significantly more than the 5 '-end.

These data suggest that although the KefC activity is conserved among unrelated Gram-negative bacteria there is little conservation of the DNA sequences. Further, even within the enteric group, the DNA sequence appears to have diverged significantly. No DNA sequence homology was detected by hybridization with any of the Gram-positive species even though Staph. aureus displayed KefC-type activity.

\section{Discussion}

The data presented confirm the presence of a KefC-class of transport system in a range of bacteria and thus suggests that the regulation of $\mathrm{K}^{+}$efflux by glutathione is a widespread phenomenon. There are two other reports of organisms that possess this system; Vibrio alginolyticus (Nakamura et al., 1986) and Anacystis nidulans (E. Padan, personal communication). DNA from $V$. alginolyticus does not hybridize to the $E$. coli kefC gene (T. Nakamura, personal communication). The system appears to be widespread among Gram-negative bacteria, but is absent from Gram-positive bacteria, with the exception of Staph. aureus. The system is also absent from Saccharomyces cerevisiae, although this organism does have significant pools of glutathione (unpublished data).

The lack of activity in most of the Gram-positive bacteria tested could have been explained by the previously noted failure of these organisms to synthesize significant quantities of glutathione (Fahey et al., 1978). This objection was overcome in our work by growing the cells in complex media that contained glutathione. Thus many of the organisms accumulated glutathione from their surroundings and consequently the absence of KefC activity represents the lack of the relevant transport components.

The formation of ESG and $S$-carboxymethylglutathione are likely to be spontaneous events arising from the nucleophilic attack on NEM and iodoacetate, respectively, by glutathione. Other activators of the KefC system can only be synthesized through the intervention of the glutathione $S$-transferase (GST), for example 2,4-dinitrophenyl-S-glutathione formed from chlorodinitrobenzene (Elmore et al., 1990). While it is known that GSTs are widespread in Gram-negative bacteria 


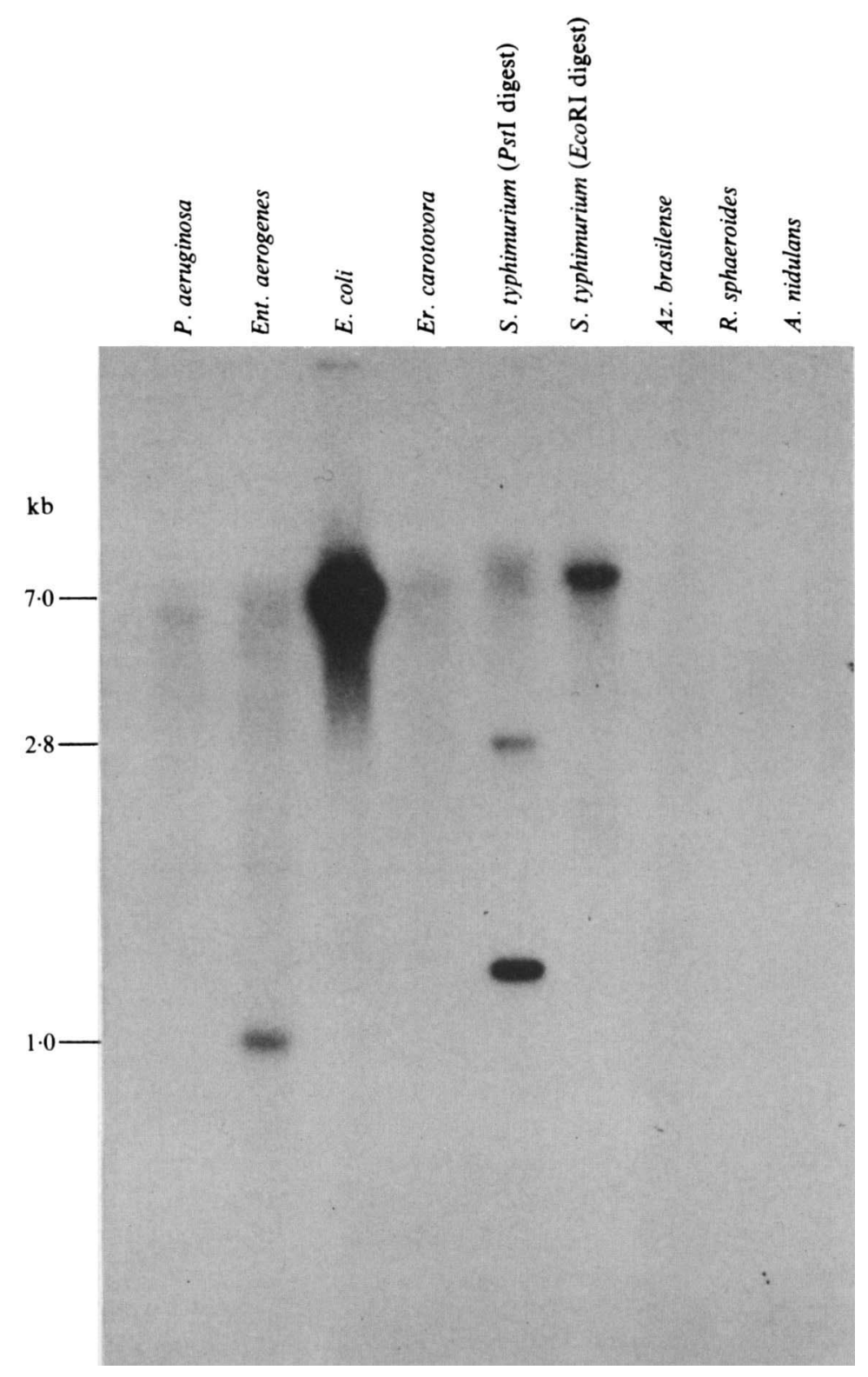

Fig. 4. Detection of genes homologous to $E$. coli $k e f C$. Southern hybridization was carried out as described in Methods. Approximately 3-5 $\mu$ g DNA was loaded onto each track of the gel. there does not appear to have been a systematic evaluation of their presence in Gram-positive bacteria (Piccolomini et al., 1989). The role of GST in Gramnegative bacteria is not completely resolved since there are no mutants lacking this enzyme at the present time. However, mutants lacking glutathione, an essential co-substrate for GST, grow normally except when challenged with reactive chemical species such as NEM and iodoacetate (Apontoweil \& Berends, 1975). Further, bacterial glutathione and GST activity have been implicated in reducing the toxicity of both 3-fluoro- and 3-chloro-2,4-dinitrobenzene (Summer \& Goggelmann,
1980). This implies that while the GST function is not essential for growth and survival of bacterial cells it is essential for detoxification of reactive chemical species.

The absence of an obvious phenotype, other than loss of NEM-elicited $\mathrm{K}^{+}$efflux, in kefB and kefC mutants of E. coli (Booth et al., 1985) raised the possibility that these glutathione-regulated transport components have no significant role in cell physiology. The presence of this system in such a wide group of bacteria, illustrated by this study, suggests that the system has a function and that an understanding of the role of the system may come from a wider investigation of the metabolism of 
glutathione and the physiology of mutants under conditions of stress associated with chemical challenge. Such studies are now under way in our laboratory.

The authors acknowledge the generous support of the SERC (grant no. GR/E31543 and studentships to G.Y.R. and A.J.L.). We wish to express our thanks to Dr Rosie Waterhouse for her helpful advice on the isolation of DNA from diverse species and to colleagues in the Department for sharing advice on Southern hybridization. We wish to thank Dr Neil Hunter and Dr Etana Padan for DNA samples.

\section{References}

APONTOWEIL, A. \& BERENDS, W. (1975). Isolation and characterization of glutathione-deficient mutants of Escherichia coli. Biochimica et Biophysica Acta 399, 10-22.

BAKKER, E. P.\& MANGERICH, W. E. (1982). $N$-Ethylmaleimide induces $\mathrm{K}^{+-} \mathrm{H}^{+}$antiport activity in Escherichia coli $\mathrm{K}-12$. FEBS Letters 140 , $177-180$.

BakKer, E. P., BoOth, I. R., Dinnbier, U., EPSTein, W. \& GaJewsKa, A. (1987). Evidence for multiple potassium export systems in Escherichia coli. Journal of Bacteriology 169, 3743-3749.

Booth, I. R., Epstein, W., Giffard, P. M. \& Rowland, G. C. (1985). Roles of the $\operatorname{trk} B$ and $t r k C$ gene products of Escherichia coli in potassium transport. Biochimie 67, 83-90.

Bossemeyer, D., Borchard, A., Dosch, D. C., Helmer, G. C., EPSTEIN, W., BoOTh, I. R. \& BAKKeR, E. P. (1989a). K+'transport protein TrkA of Escherichia coli is a peripheral membrane protein that requires other trk gene products for attachment to the cytoplasmic membrane. Journal of Biological Chemistry 264, 16403-16410.

Bossemeyer, D., Sclosser, A. \& Bakker, E. P. (1989b). Specific caesium transport via the Escherichia coli Kup (TrkD) $\mathrm{K}^{+}$uptake system. Journal of Bacteriology 171, 2219-2221.

Davis, R. W., Thomas, N., Cameron, J., St John, T. P., Schere, S. \& PADGETT, R. A. (1980). Rapid DNA isolations for enzymatic and hybridization analysis. Methods in Enzymology 65, 404-411.

Dosch, D. C., Helmer, G. L., Sutton, S. H., Salvacion, F. F. \& EPSTEIN, W. (1991). Genetic analysis of potassium transport loci in Escherichia coli: evidence for three constitutive systems mediating uptake of potassium. Journal of Bacteriology 173, 687-696.

Elmore, M. J., Lamb, A. J., Ritchie, G. Y., Douglas, R. M., Munro, A., GajewsKa, A. \& BoOth, I. R. (1990). Activation of potassium efflux from Escherichia coli by glutathione metabolites. Molecular Microbiology 4, 405-412.
EPSTEIN, W. (1986). Osmoregulation by potassium transport in Escherichia coli. FEMS Microbiology Reviews 39, 73-78.

EPSTEIN, W. \& KIM, B. S. (1971). Potassium transport loci in Escherichia coli. Journal of Bacteriology 108, 639-644.

EPSTEIN, W. \& SchULTZ, S. G. (1965). Cation transport in Escherichia coli. V. Regulation of cation content. Journal of General Physiology 49, 221-234.

Fahey, R. C., Brown, W. C., Adams, W. B. \& Worhsam, M. B. (1978). Occurrence of glutathione in bacterial cells. Journal of Bacteriology 133, 1126-1129.

FeinberG, A. P. \& Vogelstein, B. (1983). A technique for radiolabelling DNA restriction endonuclease fragments to high specific activity. Analytical Biochemistry 132, 6-13.

LAIMINS, L. A., RHOADS, D. B. \& EPSTEIN, W. (1981). Osmotic control of $k d p$ operon expression in Escherichia coli. Proceedings of the National Academy of Sciences of the United States of America 74, 464-468.

Maniatis, T., Fritsch, E. F. \& SambrooK, J. (1982). Molecular Cloning: a Laboratory Manual. Cold Spring Harbor. NY: Cold Spring Harbor Laboratory.

MARmUR, J. A. (1961). Procedure for the isolation of deoxyribonucleic acid from microorganisms. Journal of Molecular Biology 3, 208-213.

MeURY, J., Leball, S. \& KePES, A. (1980). Opening of potassium channels in Escherichia coli by thiol reagents and recovery of potassium tightness. European Journal of Biochemistry 113, 33-38.

MEURY, J., Robin, A. \& MonNier-Champeix, P. (1985). Turgor controlled fluxes and their pathways in Escherichia coli. European Journal of Biochemistry 151, 613-619.

MunRo, A. W., Ritchie, G. Y., Lamb, A. J., Douglas, R. M. \& BooTH, I. R. (1991). The cloning and DNA sequence of the gene for the glutathione-regulated potassium efflux system KefC of Escherichia coli. Molecular Microbiology 5 (in the Press).

Nakamura, T., Tokuda, H. \& Unemoto, T. (1986). $N$-Ethylmaleimide desensitizes the $\mathrm{pH}$-dependent $\mathrm{K}^{+}-\mathrm{H}^{+}$antiporter in the marine bacterium Vibrio alginolyticus. Biochemical and Biophysical Research Communications 136, 1030-1035.

Piccolomini, R., Di Ilio, C., Aceto, A., Allocati, N., Faraone, A., Cellini, L., Ravagnan, G. \& Federici, G. (1989). Glutathione transferase in bacteria: subunit composition and antigenic characterization. Journal of General Microbiology 135, 3119-3125.

RHOADS, D. B. \& EPSTEIN, W. (1978). Cation transport in Escherichia coli. IX. Regulation of $\mathrm{K}^{+}$transport. Journal of General Physiology 72 , 283-295.

Rowland, G. C., Giffard, P. M. \& Booth, I. R. (1984). Genetic studies of the phs locus of Escherichia coli, a mutation causing pleiotropic lesions in metabolism and $\mathrm{pH}$ homeostasis. FEBS Letters 173, 295-300.

SMITH, D. \& Calvo, J. (1980). Nucleotide sequence of the E. coli gene for dihydrofolate reductase. Nucleic Acids Research 8, 2255-2275.

Summer, K.-H. \& GoggelmanN, W. (1980). Mutagenicity of 1-fluoro2,4-dinitrobenzene is affected by bacterial glutathione. Mutation Research 70, 173-178. 